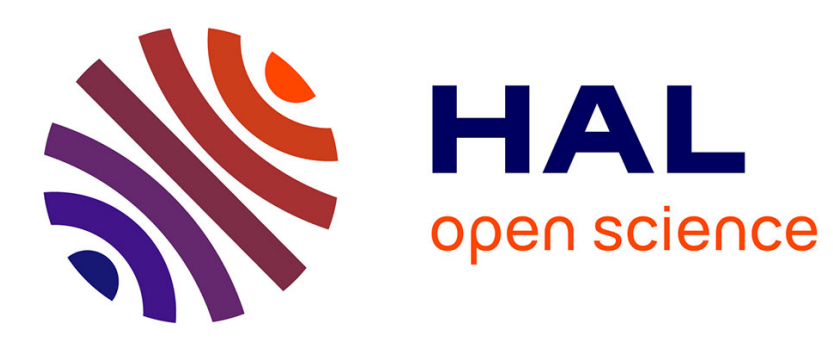

\title{
Delay of gametogenesis and spawning by constant illumination of rainbow trout (Salmo gairdneri) during the first reproductive cycle
}

\author{
A. Bourlier, Roland Billard
}

\section{- To cite this version:}

A. Bourlier, Roland Billard. Delay of gametogenesis and spawning by constant illumination of rainbow trout (Salmo gairdneri) during the first reproductive cycle. Canadian Journal of Zoology, 1984, 62 (11), pp.2183-2187. 10.1139/z84-317 . hal-01600575

\section{HAL Id: hal-01600575 \\ https://hal.science/hal-01600575}

Submitted on 2 Jun 2020

HAL is a multi-disciplinary open access archive for the deposit and dissemination of scientific research documents, whether they are published or not. The documents may come from teaching and research institutions in France or abroad, or from public or private research centers.
L'archive ouverte pluridisciplinaire HAL, est destinée au dépôt et à la diffusion de documents scientifiques de niveau recherche, publiés ou non, émanant des établissements d'enseignement et de recherche français ou étrangers, des laboratoires publics ou privés.

\section{다(1)(2)}

Distributed under a Creative Commons Attribution - ShareAlikel 4.0 International 


\title{
Delay of gametogenesis and spawning by constant illumination of rainbow trout (Salmo gairdneri) during the first reproductive cycle
}

\author{
A. BOURLIER' AND R. BILLARD ${ }^{2}$ \\ Station de Physiologie animale, Laboratoire de Physiologie des Poissons, Institut National de Recherches Agronomique, \\ 78350 Jouy en Josas, France \\ Received March 16, 1984
}

\begin{abstract}
BOURLIER, A., and R. BILLARD. 1984. Delay of gametogenesis and spawning by constant illumination of rainbow trout ( Salmo gairdneri) during the first reproductive cycle. Can. J. Zool. 62: 2183-2187.

Two-year-old, 500-600 g immature and prepuberal male and female rainbow trout were exposed on June 21 to continuous light (CL group) or, as a control, to the natural photoperiod in the Paris area (C group) and were kept under seasonal variation of temperature. Gametogenesis was studied by periodic sampling of the gonads for quantitative analysis of spermatogenesis and measurement of follicle diameter. Gonadotropin (GTH) profiles were measured in pituitary and plasma by radioimmunoassay. During spawning, the quantity and quality of gametes were measured. Under continuous light, gametogenesis and spawning were delayed by about 2 months as compared with the controls kept under a natural photoperiod. Delayed gametogenesis in the fish under continuous light showed some alterations. In the males, the dynamics of spermatogenesis was modified since the proportion of the germ cells in the testis was changed as compared with the controls; e.g., spermatids were present in the testicular lobules when spermiation started. The yield of spermiation measured in four samplings was lower in males under continuous light as compared with the controls. In the females, follicle diameter and gonadosomatic index tended to remain lower during vitellogenesis in the $\mathrm{CL}$ group as compared with the $\mathrm{C}$ group, but finally, the diameter of the eggs stripped and the fecundity were not different in both groups. GTH profiles were different only for the plasma in December. The pituitary GTH content was low in December in both groups and sexes, irrespective of the stage of the reproductive cycle and of the light environment. There was no difference in hepatosomatic and viscerosomatic indices between the two groups.
\end{abstract}

Bourler, A., et R. BILLARD. 1984. Delay of gametogenesis and spawning by constant illumination of rainbow trout (Salmo gairdneri) during the first reproductive cycle. Can. J. Zool. 62: 2183-2187.

Des spécimens immatures ou pré-pubertaires de mâles et de femelles de truites arc-en-ciel de 2 ans, de 500 à $600 \mathrm{~g}$, ont été exposés, à partir du 21 juin, à une lumière continue (groupe CL); un groupe de truites témoins (groupe C) ont été exposées à la photopériode naturelle de la région parisienne et ont subi les variations saisonnières de température. L'échantillonnage périodique des gonades, pour fin d'analyses quantitatives de la spermatogenèse et évaluation du diamètre des follicules, a permis de suivre la gamétogenèse. Des techniques radioimmunologiques ont été utilisées pour mesurer les variations des concentrations de l'hormone GTH dans l'hypophyse et dans le plasma. La quantité et la qualité des gamètes ont été évaluées au cours de la fraye. À la lumière continue, la gamétogenèse et la fraye sont retardées d'environ 2 mois par rapport aux poissons témoins gardés à la photopériode naturelle. De plus, la gamétogenèse ainsi retardée comporte certaines particularités. Chez les mâles, la proportion de cellules germinales dans le testicule est modifiée comparativement au groupe témoin; par exemple, il y a présence de spermatides dans les lobules testiculaires au moment où commence la spermiation. La production de sperme, telle que mesurée dans quatre échantillons, est plus faible chez les mâles soumis à la lumière continue que chez les poissons témoins. Chez les femelles, durant la gamétogenèse, le diamètre des follicules et l'indice gonadosomatique ont tendance à être plus faibles chez le groupe CL que chez les poissons témoins, mais le diamètre des follicules diminue éventuellement et la fécondité est la même chez les deux groupes. Les variations des concentrations de GTH ne montrent de particularités que dans le plasma, en décembre. Le contenu de GTH dans l'hypophyse est plus faible en décembre chez les deux groupes de poissons des deux sexes, quel que soit le stade de reproduction atteint et quelle que soit la photopériode. Il n'y a pas de différences entre les indices hépatosomatiques et viscérosomatiques des deux groupes de poissons.

[Traduit par le journal]

Seasonal changes in photoperiod have been shown to influence the reproductive cycle in salmonids. Increasing and decreasing day lengths are important components of the natural seasonal cycle that have been suggested to be essential to gonadal development (Eriksson and Lundqvist 1980). Many experiments have examined the effects of shortening the natural annual photoperiodic regime to 9,6 , and even 3 months. Contraction to 9 or 6 months usually advances spawning time in various species of salmonids (Hoover 1937; Hoover and Hubbard 1937; Corson 1955; Nomura 1962; Carlson and Hale 1973; Kunesh et al. 1974; Whitehead et al. 1973; Pohl et al. 1982). Contraction to 3 months gives inconsistent results with erratic ovulation and spermiation occurring over a period of several months (Pohl et al. 1982). Spawning in salmonids can also be advanced by modifying the decreasing

\footnotetext{
'Present address: Les Salmonidés d'Aquitaine, Sarrance, F-64490 Bedous, France.

${ }^{2}$ Author to whom all correspondence should be addressed.
}

part of the natural cycle either by a progressive decrease from 16 to $8 \mathrm{~h} \mathrm{light/day} \mathrm{over} \mathrm{a} \mathrm{period} \mathrm{of} \mathrm{several} \mathrm{months} \mathrm{(Combs}$ et al. 1959; Hazard and Eddy 1951; Goryczko 1972; Breton and Billard 1977; Billard and Breton 1977) or by an abrupt change from long (16 h light : $8 \mathrm{~h}$ dark, LD 16:8) to short $(8 \mathrm{~h}$ light : $16 \mathrm{~h}$ dark, LD $8: 16$ ) days.

Using decreasing photoperiod, it is possible to advance the spawning by several weeks (Combs et al. 1959; Shiraishi and Fukuda 1966; Billard et al. 1981; Bromage et al. 1982; Takashima and Yamada 1984). Lundqvist (1980) did not advance functional maturity in male Atlantic salmon when photoperiod was abruptly changed to short day (LD 6:18) in August.

Retardation of sexual maturity has also been attempted by light manipulation. Spawning can be delayed by expanding the natural seasonal cycle of day length (MacQuarrie et al. 1978) or by keeping the fish under constant long photoperiod after the summer solstice (Lundqvist 1980). In some cases, this method of exposing fish to constant light (LD 24:0) or constant 


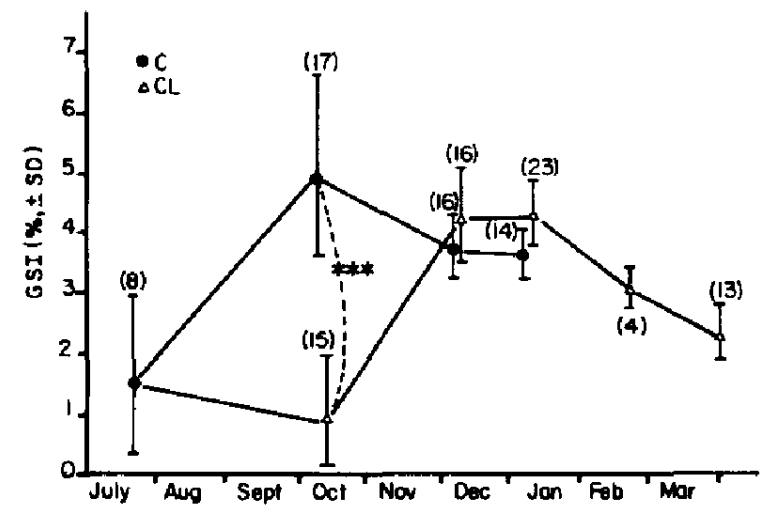

FIG. 1. Changes in GSI in male rainbow trout submitted to normal photoperiod (C) or continuous light (CL). $* * *, P<0.001 ; n$ is in parentheses.

long days has been found to advance maturity in male brook trout (Poston and Livingston 1971) and rainbow trout (Skarphédinsson et al. 1982), Constant light or constant dark do not prevent gonadal development (Shiraishi and Fukuda 1966). Poston and Livingston (1971), Pyle (1969), and Bieniarz (1973) obtained normal spawning in fish kept under these regimes. The present experiment explores the feasibility of delaying gametogenesis and spawning in male and female rainbow trout undergoing their first reproductive cycle by exposing the fish to continuous light after the summer solstice.

\section{Material and methods}

Male and fenale rainbow trout (Lubin strain) bred in raceways in our experimental facilities were in their 2 nd year of life (body weight, $500-600 \mathrm{~g}$ ). The experiment began on June 21 ; two groups of 150 fish each were transferred to $10-\mathrm{m}^{3}$ raceways (flow rate, $10 \mathrm{~m}^{3} / \mathrm{h}$ ), one under continuous light (group $\mathrm{CL}$ ) and a control group under natural light (group C). In group CL, light was provided by $100-\mathrm{W}$ lamps generating $1300 \mathrm{~lx}$ at the surface of the water and $160 \mathrm{~lx}$ at the bottom of the raceways. In the $\mathrm{C}$ group, light measured on a sunny day was $1500 \mathrm{~lx}$ at the surface and $180 \mathrm{~lx}$ at the bottom. Both groups were subjected to seasonal variations of water temperature $\left(3-16^{\circ} \mathrm{C}\right)$.

The fish were given $7 \mathrm{~mm}$ dry brood stock pellets (Trouw, France), at a daily rate of $1 \%$ of body weight twice a day at 0900 and 1600 on working days and once on Saturday and Sunday; they were not fed in the 3 days preceding checking or egg or milt sampling. To prevent fungus infection a weekly Malachite green treatment was also given.

Each group was divided into two equal subgroups, A and B. Samples of fish in subgroup A were taken and killed in July, October, and December 1978, January, February, and March 1979, and in some cases in July 1979.

In October, December, and January only maturing or mature fish were killed. Plasma and pituitaries were collected and stored at $-20^{\circ} \mathrm{C}$ until a radioimmunoassay for trout gonadotropin (tGTH) was performed according to Breton and Billard (1977). The gonads and liver were weighed to calculate the gonadosomatic (GSI) and hepatosomatic (HSI) indices. The weight of the liver and the digestive tract (gut and perivisceral fat) were added to calculate the viscera : body weight ratio (viscerosomatic index, VSI). GSI, HSI, and VSI were calculated using the weight of the carcass only, i.e., body without gonads or viscera $\left(=100 \times \frac{\text { organ weight }}{\text { carcass weight }}\right)$. The testes wcre fixed in Bouin-Hollande and processed for quantitative analysis of spermatogenesis according to Billard et al. (1974). The ovaries were fixed in $10 \%$ Formalin to measure the diameter of vitellogenic oocytes $(>1$ $\mathrm{mm}$ ). In subgroup $B$ the fish were controlled twice a month from November to March for ovulation and spermiation. In males the volume (millilitres) of sperm collected after stripping was measured; in females the ova were counted, weighed, and their diameters (milli-

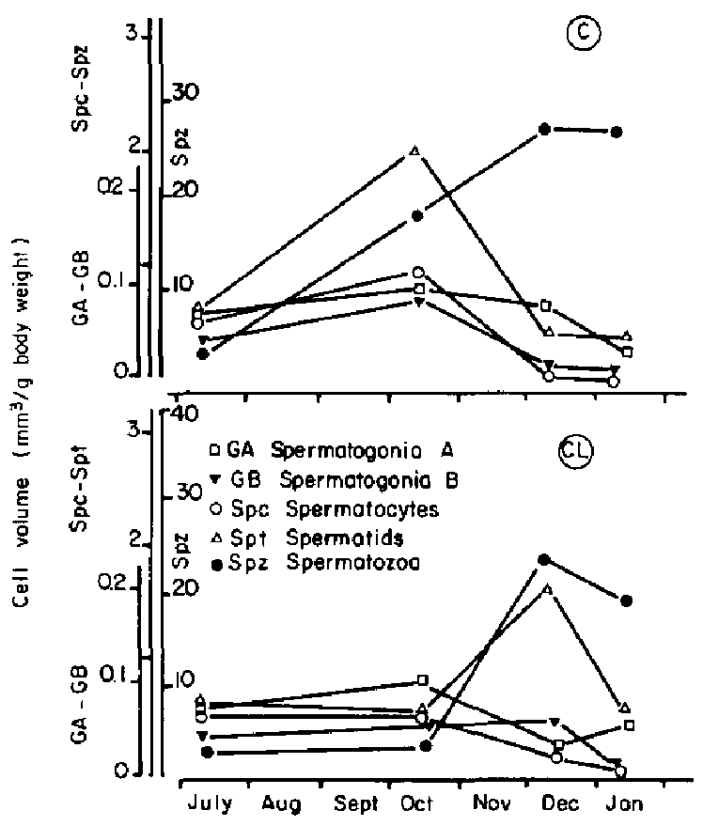

FIG. 2. Quantitative analysis of spermatogenesis in male rainbow trout submitted to normal photoperiod (C) or to continuous light (CL).

metres) were measured. The fertilizing ability of the sperm and the fertility of the ova ( $\delta \mathrm{CL} \times \$ \mathrm{C}$ and $\delta \mathrm{C} \times q \mathrm{CL}$ ) were estimated by the percentage of developing eggs after incubation for 20 days at $10^{\circ} \mathrm{C}$. Artificial insemination was carried out on batches of about 200 ova according to Billard (1977). GSI, HSI, and VSI were compared by analysis of variance (Anova). The data from the quantitative analysis of spermatogenesis and the GTH values were compared by using analysis of variance after a $\log _{10}$ transformation for homogeneity of the values. Percentages of fertilization were compared by the $\chi^{2}$ test.

\section{Results}

Spermatogenesis was delayed in group CL; for example, in October the GSI of the control group $\mathrm{C}$ reached a maximal value while it was still at a minimum in group CL (Fig. 1). The maximum GSI in group CL, observed in December and January, was not significantly different from the GSI of the controls in October. Histological investigation showed that spermatogenesis occurred mainly between July and October in group $\mathrm{C}$ and in October and December in group CL (Fig. 2). In the preexperimental controls sampled in June, it was noted that spermatogenesis had been initiated since most of the germ cell types were found in the testis, including a small number of spermatozoa. The situation remained similar in July in both groups. In group $\mathrm{C}$, these germ cells divide actively after July; by October, spermatids were numerous and about half of the spermatozoa were already formed. In group $\mathrm{CL}$, the process of spermatogenesis appeared to be inhibited until October. However, in December, spermatids were abundant in the testis of fish in this group.

In both groups, the VSI decreased during spermatogenesis from 7 to $3.5 \%$, but more rapidly in group $C$ than in group CL. Liver weight remained stable during spermatogenesis (1-1.5\% of body weight) in both groups. The levels of pituitary GTH in groups $\mathrm{C}$ and $\mathrm{CL}$ was not significantly different and remained below $1 \mu \mathrm{g} \mathrm{tGTH} / \mathrm{mg}$ of fresh pituitary. Plasma GTH remained below $8 \mathrm{ng} / \mathrm{mL}$ plasma during the cycle in the CL group and slightly exceeded $10 \mathrm{ng} / \mathrm{mL}$ in December in the $C$ group, but values were not significantly different in both groups. The cumulative percentage of males found in spermiation (Fig. 3) showed that about $40 \%$ of the male and 


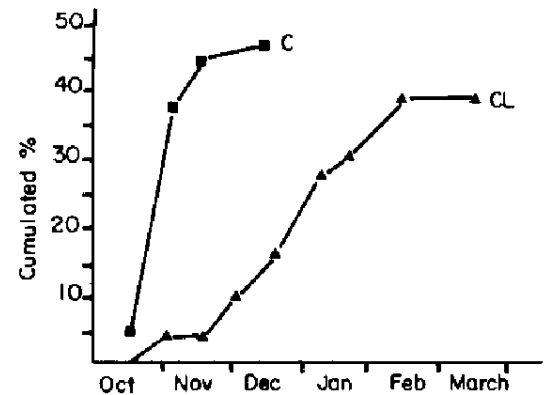

FIG. 3. Cumulative percentages of males in spermiation after periodic examination (subgroup B). C, control; $\mathrm{CL}$, continuous light.

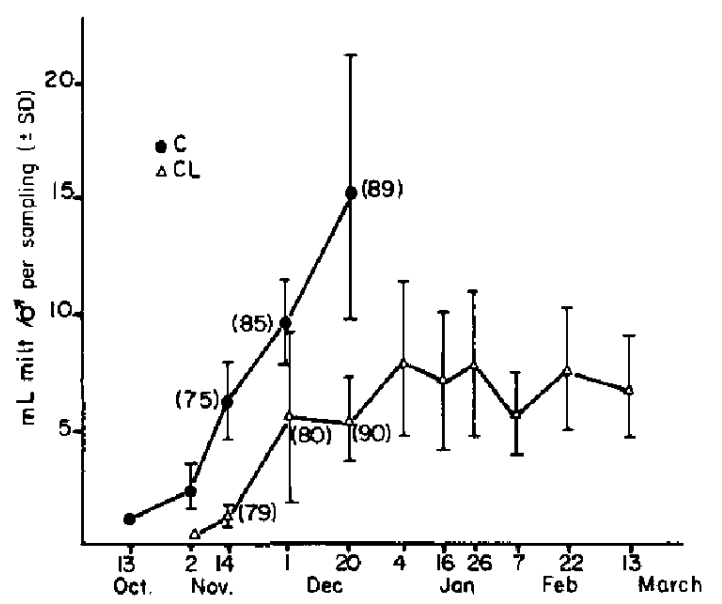

FIG. 4. Volume of milt collected during spermiation in group $\mathrm{C}$ (control) and group $\mathrm{CL}$ (constant light). The fertilizing ability of sperm expressed in percent of egg development after 200 degree-days is shown in parentheses.

female population combined was mature in group CL, and at least $45 \%$ was mature in group $\mathrm{C}$. Owing to a severe fungus infection, most of the group $\mathrm{C}$ males died in January.

Spermiation in group $\mathrm{CL}$ was delayed by 9 weeks compared with the control group. The volume of milt collected per male during the first four samplings was significantly higher in group $C$ than in group $\mathrm{CL}(P<0.001)$ (Fig. 4). The fertilizing ability of the sperm did not appear to be modified by the light treatment (see Fig. 4).

In females that matured during the course of the experiment, the process of oogenesis was delayed by continuous light as shown by the changes in GSI in subgroup A (Fig. 5). The GSI rose earlier and more rapidly in group $\mathrm{C}$ than in group $\mathrm{CL}$ and reached a higher maximum $(P<0.025)$. Ovulation (observed in subgroup B fish submitted to frequent inspection) occurred in November in group $\mathrm{C}$ and between December and March in group CL (Fig. 5). Only 15\% of the total population (about $30 \%$ of the females) matured as three summer old fish (Fig. 5).

Changes in follicle size during vitellogenesis are shown in Fig. 6 (subgroup A). The follicles grew more slowly and were significantly smaller in group $\mathrm{CL}$ compared with the follicle from fish in group C. However, this was not true for the fish in the subgroup B (submitted to bimonthly sampling during the spawning season) in which the size of oocytes and fecundity were similar to the controls (Table 1). The percentage of developing eggs was also similar in both groups: $91-88 \%$ in December and $85-87 \%$ in January in the $C$ and $C L$ groups, respectively. GTH tended to be higher up to December in both the plasma and the pituitary of group $\mathrm{C}$ females, but the differences were significant only in December for plasma GTH

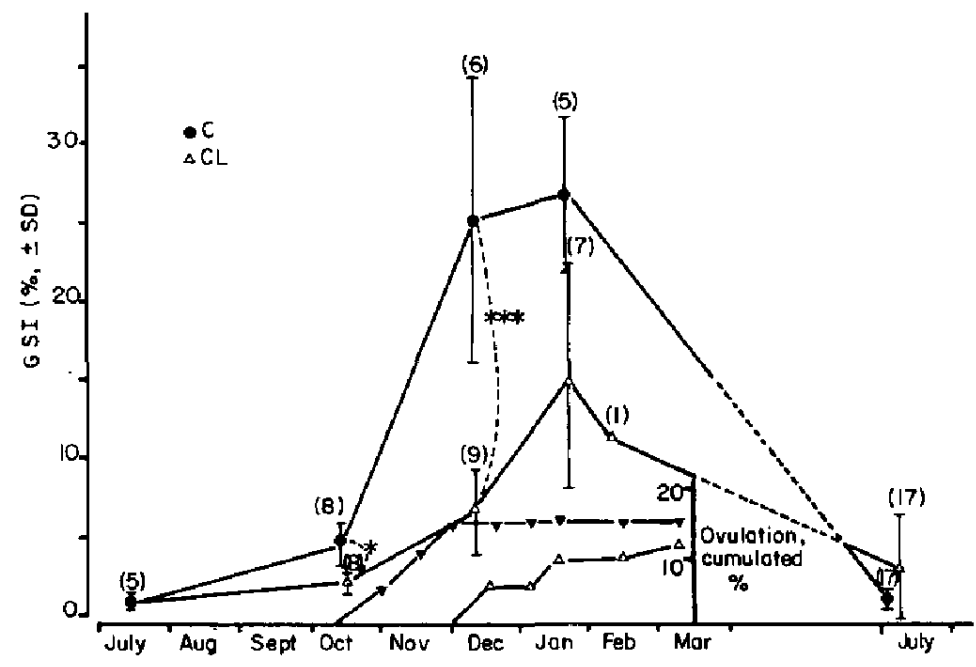

FIG. 5. Changes in GSI in female rainbow trout submitted to normal photoperiod $(C)$ or continuous light (CL) and cumulative percentage of females ovulated at periodic examination (subgroup B). $*, P<0.05 ; * * *, P<0.001 ; n$ is in parentheses.

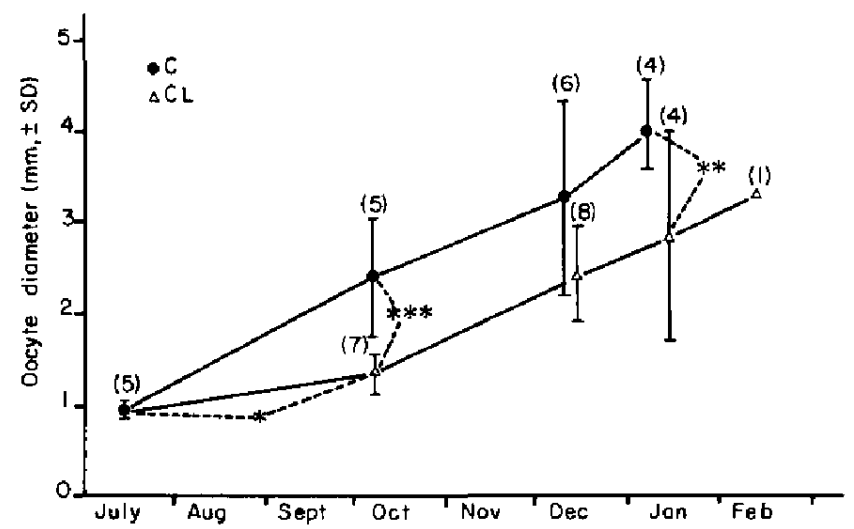

FIG. 6. Changes in follicle size during vitellogenesis in female rainbow trout (subgroup A). C, control; $\mathrm{CL}$, constant; ${ }^{*}, P<0.05$; **, $P<0.025 ; * * *, P<0.005 ; n$ is in parentheses.

(Fig. 7).

During oogenesis, the HSI increased significantly $(P<$ 0.05 ) from 1.5 to $2.5 \%$ between October and January in group $\mathrm{CL}$, while it remained nearly constant in the controls. The VSI decreased from 7 to $4 \%$ in both groups, but did so earlier in the control group.

\section{Discussion}

This experiment shows that when individuals of sexually immature male and female trout were kept under ambient seasonal temperature and continuous light conditions after the summer solstice, it was possible to delay their final sexual maturity by about 2 months. In contrast, fish kept as control under a seasonally decreasing photoperiod regime matured sexually at the normal time in October-November.

Histological analysis showed that the constant light regime delayed the processes of both vitellogenesis and spermatogenesis. After completion of gametogenesis gamete release occurred normally. Some differences between the two groups in the study were the following. (i) The dynamics of spermatogenesis and vitellogenesis in group $\mathrm{CL}$ seemed to be somewhat altered. There was a slight difference in the proportion of male germ cells found in October in group $\mathrm{C}$ and in December in group $\mathrm{CL}$; this may have been due to a difference in spermato- 
TABLE 1. Number of ova per female (absolute fecundity) or per body weight (relative fecundity) and size of the ova in ovulated females in subgroup $B$

\begin{tabular}{lccccc}
\hline \hline Group & $\begin{array}{c}\text { Body weight }{ }^{a} \\
(\mathrm{~g})\end{array}$ & \multicolumn{2}{c}{ Fecundity } & $\begin{array}{c}\text { Ova } \\
\text { diameter } \\
(\mathrm{mm})\end{array}$ & $\begin{array}{c}\text { Weight of } \\
\text { 100 ova } \\
(\mathrm{g})\end{array}$ \\
\cline { 3 - 6 } $\mathrm{C}$ & $676.50 \pm 82.58$ & $2447 \pm 810$ & $3620 \pm 957$ & $3.80 \pm 0.74$ & $5.85 \pm 0.48$ \\
CL & $641.50 \pm 69.95$ & $2403 \pm 525$ & $3749 \pm 727$ & $3.65 \pm 0.22$ & $5.64 \pm 0.30$ \\
\hline
\end{tabular}

"Weight of the females without ova.

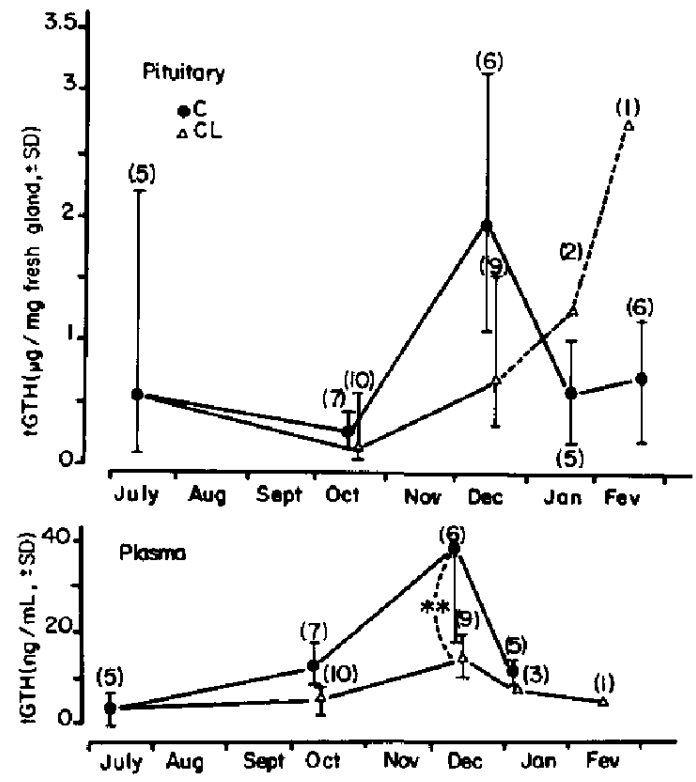

Fig. 7. Changes in plasma and pituitary tGTH ( $\log _{10}$ transformation of the values) in female rainbow trout (subgroup A). C, control group; CL, continuous group. Pituitary GTH is expressed as micrograms per milligrams of fresh gland. ${ }^{* *}, P<0.025 ; n$ is in parentheses.

genetic stage but spermiation started in December while spermatids were still numerous in the testis. It seems that all spermatids were not all converted into spermatozoa since the latter did not increase in January suggesting an alteration of the spermatogenetic function. As seen from the first four samplings, the yield of spermiation appeared lower in group CL but the fertilizing ability of the sperm remained identical in the two groups, at least at the low dilution rate used. In the females, the GSI was lower in group CL than in group $\mathrm{C}$ and the oocyte diameter of the first group remained lower than that of the controls during most of the process of vitellogenesis; at the time for ovulation the ova were found to be similar in number, size, and fertility. (ii) In December, plasma GTH appeared to be higher in group $C$ than in group $C L$, at least in the females. This may be related to the lower efficiency of vitellogenesis in group CL. However, although the peri- and post-ovulatory rise of GTH (first noted by Jalabert and Breton (1980) in rainbow trout) appeared to be less in group $\mathrm{CL}$, the yield of ovulation was not altered since fecundity remained similar in both groups. It is also interesting to note that the pattern of secretion or the pituitary content tended to be the same for the males and females of both groups with a rise in December, irrespective of the stage of the reproductive cycle and the light environment. The plasma and pituitary GTH values were in the same range as in other studies on rainbow trout (Billard et al. 1978) and on other salmonids (Crim et al. 1975; Breton et al. 1983). (iii) Some differences were also noted in the HSI and VSI of the two groups. In the females, the
HSI was higher in group CL than in group C. In the latter, there was not much variation between July and December, but Nomura (1962), as well as R. Billard (unpublished data), found some in rainbow and brown trout, respectively. During gametogenesis and gamete release, there was a decline in VSI in both sexes, but it was slightly delayed in group CL. This drop in VSI may reflect a transfer of the perivisceral fat to the gonad.

Other experiments have shown that long days or continuous light can delay sexual maturity in salmonids. Shiraishi and Fukuda (1966) observed a delay of 2-3 months in four species (Oncorhynchus nerka, $O$. rhodurus, Salvelinus fontinalis, and Salmo gairdneri) after exposure to LD 16:8 and LD 24:0 from June to February at a constant temperature of $9^{\circ} \mathrm{C}$. In several other experiments carried out under a natural thermoperiod regime and usually with a shorter period of exposure to long days ( $2-4$ months), maturity was also delayed under a constant LD 17:7 rising light from September to December in Salvelinus fontinalis (Allison 1951; Hazard and Eddy 1951), LD $4: 20$ in O. nerka (Combs et al. 1959), and LD 20:4 in Salmo salar (Lundqvist 1980). On the contrary, an advancement of the spawning period has been reported after exposure of female rainbow trout to long days, LD 16:8 (Bromage et al. 1982), or of males and females to LD 19:5 (Skarphédinsson et al. 1982). Under continuous light and a constant temperature of $8.3^{\circ} \mathrm{C}$, sexual maturity was advanced by 18 weeks in males and delayed by 4 weeks in female brown trout (Poston and Livingston 1971). In most of these experiments the fish were prepuberal, but age, stage of sexual development at the beginning of the experiment, percentage of maturing individuals, and quantity and quality of the gametes collected were not described. In another experiment (Bourlier and Billard 1984), it was shown that exposure of the fish to altered photoperiod regimes during the first reproductive cycle resulted in some egg retention at the end of the following reproduction cycle carried out either under natural photoperiod or under long days.

\section{Acknowledgements}

We wish to thank Dr. N. Stacey for helpful comments on the manuscript and Drs. C. Weil, B. Breton, and B. Chevassus for their advice during this work.

ALLison, N. L. 1951. Delay of spawning in eastern brook trout by means of artificial prolonged light intervals. Prog. Fish-Cult. 13: $111-116$.

BIENIARZ, K. 1973. Effects of light and darkness on incubation of eggs, length, weight and sexual maturity of sea trout (Salmo trutta L.), brown trout (Salmo trutta fario L.) and rainbow trout (Salmo irideus G.). Aquaculture, 2: 299-315.

BILlARD, R. 1977. Utilisation d'un système TRIS-glycocolle pour tamponner le dilueur d'insémination de truite. Bull. Fr. Piscic. 264: $102-112$.

BillaARd, R., and B. Breton. 1977. Sensibilité à la température des différentes étapes de la reproduction chez la truite Arc-en-ciel. Cah. 
Lab. Montereau, 5: 5-24.

Billard, R., B. Breton, A. Fostier, B. Jalabert, and C. Weil. 1978. Endocrine control of the teleost reproductive cycle and its relation to external factors: Salmonid and Cyprinid models. In Comparative endocrinology. Edited by P. J. Gaillard and H. H. Boer. Elsevier/North-Holland Biochemical Press, Amsterdam. pp. 37-48.

Billard, R., P. Reinaud, and P. Lebrenn. 1981. Effects of changes of photoperiod on gametogenesis in the rainbow trout (Salmo gairdneri). Reprod, Nutr. Dev. 21: 1009-1014.

Billard, R., A. Solari, and A. M. EsCaffre. 1974. Méthode d'analyse quantitative de la spermatogénèse des poissons téléostéens. Ann. Biol. Anim. Biochem. Biophys. 14: $87-104$.

Bourlier, A., and R. BiLlard. 1984. Delayed gametogenesis and spawning in rainbow trout (Salmo gairdneri) kept under permanent light during the first and second reproductive cycles. Aquaculture. In press.

BRETON, B., and R. BILLARD. 1977. Effects of light and temperature on the plasma gonadotropin and spermatogenesis in the rainbow trout (Salmo gairdneri). Ann. Biol. Anim. Biochem. Biophys. 17: $331-340$.

BRETON, B., A. Fostier, Y. Zohar, Y. LE BAIL, and R. BILlARd. 1983. Gonadotropine glycoprotéique maturante et estradiol $17 \beta$ pendant le cycle reproducteur chez la truite fario (Salmo trutta) femelle. Gen. Comp. Endocrinol. 49: 220-231.

Bromage, N., C. Whitehead, J. ElloitT, B. Breton, and A. MATTY. 1982. Investigations into the importance of daylength on the photoperiodic control of reproduction in the female rainbow trout. In Reproductive physiology of fish. Compilers C. J. J. Richter and J. H. Th. Goos. PUDOC, Wageningen, Netherlands. pp. 233-236.

Carlson, A. R., and J. C. Hale. 1973. Early maturation of brook trout in the laboratory. Prog. Fish-Cult. 35: 150-153.

Crim, L. W., E. G. WATTS, and D. M. Evans. 1975. The plasma gonadotropin profile during sexual maturation in a variety of salmonid fishes. Gen. Comp. Endocrinol. 27: 62-70.

ComBs, B. D., R. E. Burrows, and R. C. BIGEJ. 1959. The effect of controlled light on the maturation of adult blueback salmon. Prog. Fish-Cult. 21: $63-69$.

CoRson, B. W. 1955. Four years' progress in the use of artificially controlled light to induce early spawning of brook trout. Prog. Fish-Cult. 17: 99-102.

ERICKSON, L. O., and H. LuNDQVIST. 1980. Photoperiod entrains ripening by its differential effect in salmon. Naturwissenschaften, 67: $202-203$.

GoRYCZKO, K. 1972. A change of the spawning season in rainbow trout (Salmo gairdneri). Roczn. Nauk. Roln. Ser. H, 94: 57-68.

HAZARD, T. P., and R. E. EDDY. 1951. Modification of the sexual cycle in brook trout (Salvelinus fontinalis) by control of light.
Trans. Am. Fish. Soc. 80: 158-162.

HoOvER, E. E. 1937. Experimental modification of the sexual cycle in trout by control of light. Sciences, (N.Y.), 86: 425-426.

Hoover, E. E., and H. E. HubBard. 1937. Modification of the sexual cycle in trout by control of light. Copeia, 1937: 206-210.

JALABERT, B., et B. BRETON. 1980. Evolution de la gonadotropine plasmatique t-GTH après l'ovulation chez la truite Arc-en-ciel (Salmo gairdneri R.) et influence de la rétention des ovules. C.R. Hebd. Seances Acad. Sci. Ser. D, 290: 799-801.

Kunesh, W. H., W. J. Freshman, M. HoEhm, and N. G. NordiN. 1974. Altering the spawning cycle of rainbow trout by control of artificial light. Prog. Fish-Cult. 36: 225-226.

LUNDQVIST, H. 1980. Influence of photoperiod on growth in Baltic salmon parr (Salmo salar L.) with special reference to the effect of precocious sexual maturation. Can. J. Zool. 58: 940-944.

MaCQuarrie, D. W. J. R. MARKert, and W. E. VANSTONE. 1978. Photoperiod induced off-season spawning of coho salmon (Oncorhynchus kisutch). Ann. Biol. Anim. Biochem. Biophys. 18: $1051-1058$.

Nomura, M. 1962. Studies on reproduction of rainbow trout, Salmo gairdneri, with special reference to egg taking. III. Acceleration of spawning by control of light. Bull. Jap. Soc. Sci. Fish. 28: 1070-1076.

POHL, M., R. SCHMIDT, and W. Holtz. 1982. Manipulation of spawning activity in rainbow trout by light programs. In Reproductive physiology of fish. Compilers C. J. J. Richter and J. H.Th. Goos. PUDOC, Wageningen, Netherlands, p. 242.

Poston, H. A., and D. L. Livingston. 1971. The effect of continuous darkness and continuous light on the functional sexual maturity of brook trout during their second reproductive cycle. Fish. Res. Bull. N.Y. Conserv. Dep. 33: 25-29.

PYLE, E. A. 1969. The effect of constant light or constant darkness on the growth and sexual maturity of brook trout. Fish. Res. Bull. N.Y. Conserv. Dep. 31: 13-19.

SHIRAISHI, Y., and Y. FUKUDA. 1966. The relation between the daylength and the maturation in four species of salmonid fish. Bull. Freshwater Fish. Res. Lab. (Tokyo), 16: 103-111.

SKARPHÉdinsson, O., A. P. SCotT, and V. J. BYE. 1982. Long photoperiods stimulate gonad development in rainbow trout. In Reproductive physiology of fish. Compilers C. J. J. Richter and J. H. Th. Goos. PUDOC, Wageningen, Netherlands. p. 243.

TAKASHIMA, F., and Y. YAMADA. 1984. Control of maturation in masu salmon by manipulation of photoperiod. International Symposium on Salmonid Reproduction, September 1983, Seattle, WA.

Whitehead, C., N. R. Bromage, J. R. M. Forster, and A. J. MATTY. 1978. The effects of alterations in photoperiod on ovarian development and spawning time in the rainbow trout (Salmo gairdneri). Ann. Biol. Anim. Biochem. Biophys. 18: 1035-1043. 